\title{
RESEARCH
}

Open Access

\section{Muscle atrophy induced by overexpression of ALAS2 is related to muscle mitochondrial dysfunction}

\author{
Yahui Peng ${ }^{1,3,4+}$, Jihong Li $\mathrm{i}^{1,3,4+}$, Dixian Luo², Shuai Zhang ${ }^{1,3,4}$, Sijia Li $i^{1,3,4}$, Dayong Wang ${ }^{1,3,4}$, Xidi Wang ${ }^{1,3,4}$,

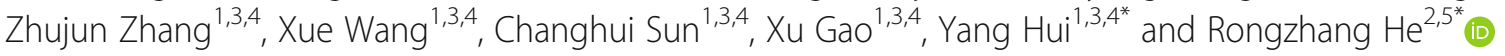

\begin{abstract}
Background: ALAS2 (delta-aminolevulinate synthase 2) is one of the two isoenzymes catalyzing the synthesis of delta-aminolevulinic acid (ALA), which is the first precursor of heme synthesis. ALAS2-overexpressing transgenic mice (Tg mice) showed syndrome of porphyria, a series of diseases related to the heme anabolism deficiency. $\mathrm{Tg}$ mice showed an obvious decrease in muscle size. Muscle atrophy results from a decrease in protein synthesis and an increase in protein degradation, which ultimately leads to a decrease in myofiber size due to loss of contractile proteins, organelles, nuclei, and cytoplasm.
\end{abstract}

Methods: The forelimb muscle grip strength of age-matched ALAS-2 transgenic mice (Tg mice) and wild-type mice (WT mice) were measured with an automated grip strength meter. The activities of serum LDH and CK-MB were measured by Modular DPP. The histology of skeletal muscle (quadriceps femoris and gastrocnemius) was observed by hematoxylin and eosin (HE) staining, immunohistochemistry, and transmission electron microscope. Real-time PCR was used to detect mtDNA content and UCP3 mRNA expression. Evans blue dye staining was used to detect the membrane damage of the muscle fiber. Single skeletal muscle fiber diameter was measured by single-fiber analyses. Muscle adenosine triphosphate (ATP) levels were detected by a luminometric assay with an ATP assay kit.

Results: Compared with WT mice, the strength of forelimb muscle and mass of gastrocnemius were decreased in Tg mice. The activities of serum CK-MB and LDH, the number of central nuclei fibers, and Evans blue positive fibers were more than those in WT mice, while the diameter of single fibers was smaller, which were associated with suppressed expression levels of MHC, myoD1, dystrophin, atrogin1, and MuRF1. Re-expression of eMyHC was only showed in the quadriceps of Tg mice, but not in WT mice. Muscle mitochondria in Tg mice showed dysfunction with descented ATP production and mtDNA content, downregulated UCP3 mRNA expression, and swelling of mitochondria.

(Continued on next page)

\footnotetext{
*Correspondence: huiyang79@126.com; rongzhang412@163.com

${ }^{\dagger}$ Yahui Peng and Jihong Li contributed equally to this work.

'Department of Biochemistry and Molecular Biology, Harbin Medical University, Harbin 150086, China

${ }^{2}$ Institute of Translational Medicine, National and Local Joint Engineering Laboratory of High-through Molecular Diagnostic Technology, the First People's Hospital of Chenzhou, The First Affiliated Hospital of Xiangnan University, Chenzhou 423000, China

Full list of author information is available at the end of the article
}

C C The Author(s). 2021 Open Access This article is licensed under a Creative Commons Attribution 4.0 International License, which permits use, sharing, adaptation, distribution and reproduction in any medium or format, as long as you give appropriate credit to the original author(s) and the source, provide a link to the Creative Commons licence, and indicate if changes were made. The images or other third party material in this article are included in the article's Creative Commons licence, unless indicated otherwise in a credit line to the material. If material is not included in the article's Creative Commons licence and your intended use is not permitted by statutory regulation or exceeds the permitted use, you will need to obtain permission directly from the copyright holder. To view a copy of this licence, visit http://creativecommons.org/licenses/by/4.0/ The Creative Commons Public Domain Dedication waiver (http://creativecommons.org/publicdomain/zero/1.0/) applies to the data made available in this article, unless otherwise stated in a credit line to the data. 
(Continued from previous page)

Conclusion: ALAS2 overexpressing-transgenic mice (Tg mice) showed muscle dystrophy, which was associated with decreased atrogin-1 and MuRF-1, and closely related to mitochondrial dysfunction.

Keywords: Muscle atrophy, Mitochondrial dysfunction, Transgenic mice, Delta-aminolevulinate synthase 2

\section{Background}

The heme biosynthetic pathway begins from deltaaminolevulinic acid synthase (ALAS) catalyzing the condensation of glycine and succinyl-CoA to deltaaminolevulinic acid (ALA) in the mitochondria [1]. ALAS is coded by two genes: ALAS1 and ALAS2 [2]. ALAS1 is ubiquitously expressed in all cells, and the negative feedback is regulated by the heme pool $[3,4]$; however, ALAS2 is specifically expressed only in erythroid cells $[2,5]$ and is not inhibited by heme [6]. Bechara reported that reactive oxygen species (ROS) is formed by the metal-catalyzed aerobic oxidation of ALA at abnormally high levels [6, 7]; mitochondria are the main source of ROS and are also the primary target of oxidant-induced damage. ALA, as a putative endogenous source of ROS, induces mitochondrial swelling and transmembrane potential collapse [7], and ALA-treated rats under swimming training experienced fatigue earlier [8]. Defective mitochondrial function has been shown to cause muscle weakness [9]. The loss of mitochondria has also been shown to result in muscle wasting [10]. Notably, studies have reported abnormalities in the mitochondria during sarcopenia, muscle wasting, associated with chronic illness (cachexia), and disuse atrophy $[11,12]$.

The mitochondria produce adenosine triphosphate (ATP) as a source of chemical energy, and skeletal muscle contains abundant mitochondria. Increased mitochondrial ROS production can promote disuse muscle atrophy by increasing proteolysis and depressing protein synthesis, and ROS can contribute to mitochondrial damage and impaired the ability to produce ATP, which results in energy stress [10]. Theoretically, mitochondrial damage could decrease the level of cellular energy available for protein synthesis, and energy stress could promote proteolysis via the AMPK-FoxO3 axis [10].

Disorder of the heme biosynthesis pathway could induce porphyria. Each enzymatic alteration of the heme biosynthesis system can cause a specific porphyria [13]. The clinical manifestations include acute neurovisceral attacks, skin lesions, and muscle atrophy, which are associated with the accumulation of porphyrin precursors (5-aminolevulinic acid, porphobilinogen) and porphyrins. Muscle weakness due to porphyria can progress and lead to tetraplegia, with respiratory and bulbar paralysis [13]. ALAS2-overexpressing transgenic mice (Tg mice) showed obvious muscle atrophy. Jasmin BarmanAksözen et al. found a significant increase in the amount of ALAS2 mRNA and protein among patients with erythropoietic protoporphyria (EPP) [14]. Additionally, four recurrent gain-of-function mutations in the catalytic domain of the ALAS2 enzyme resulting in an increased ALAS2 activity have been described as being responsible for X-linked protoporphyria (XLPP) [15]. To-Figueras et al. presented convincing evidence that ALAS2 acts as a modifier gene in patients with congenital erythropoietic porphyria [16]. In this study, we reported that ALAS2 overexpressing-transgenic mice (Tg mice) showed muscle atrophy, which was associated with decreased atrogin-1 and MuRF-1, and closely related to mitochondrial dysfunction.

\section{Materials and methods \\ Animals}

ALAS2 transgenic mice were generated by the standard pronuclear injection technique using C57BL/6 mice. Briefly, mouse ALAS2 cDNA was cloned into the pCAGGS plasmid with the chicken $\beta$-actin promoter, which drove the mouse ALAS2 cDNA expression, and terminated with the poly (A) signal. All animals were identified by analysis of tail DNA by PCR. Sequences of primers were as follows $\left(5^{\prime}-3^{\prime}\right)$ : forward primer was GCCTTCTTCTTTTTCCTACAGCTC; reverse primer was GCACAATCTTGCTCTTCCTGTCTTGG. Both the ALAS2 transgenic mice and wild type mice were housed in a temperature-controlled room $\left(22{ }^{\circ} \mathrm{C}\right)$ with a 12-h light to 12 -h dark cycle. Unless otherwise noted, 6to 12-month-old male mice were used in the experiments. All procedures were approved by the Institutional Animal Care and Use Committee of Harbin Medical University.

\section{Measurement of forelimb muscle grip strength}

The forelimb muscle grip strength was measured by an automated grip strength meter (Jinan, China) as described previously [17]. Briefly, mice were lifted by their tails and made to hold a horizontal bar with their forelimbs. Next, they were pulled slowly backwards until they could no longer hold the grip. The maximal force was recorded during consecutive attempts (at least 20 attempts per mouse), and the average was set as the result.

\section{Biochemical assays}

Serum samples were separated from whole blood by centrifugation at $1,000 \times \mathrm{g}$ for 10 minutes after the blood 
was allowed to clot at room temperature for 30 minutes. The activities of serum lactate dehydrogenase (LDH), creatine kinase (CK), and creatine kinase-MB (CK-MB) were measured by Modular DPP (Roche).

\section{Processing of tissues for histology}

The gastrocnemius and/or quadriceps muscles were fixed with $4 \%$ formalin for at least $36 \mathrm{~h}$. The tissues were embedded in paraffin and cut into $4 \mu \mathrm{m}$ thick sections in the transverse myofilament direction. Then, the sections were stained with hematoxylin and eosin (HE), and the images were visualized and captured with the Olympus Bx51 microscope.

\section{Immunohistochemistry}

The sections of paraffin-embedded muscle tissue were deparaffinized in xylene and rehydrated in ethyl alcohol. Then, the sections were blocked with 1\% hydrogen peroxide $\left(\mathrm{H}_{2} \mathrm{O}_{2}\right)$ in distilled water for $10 \mathrm{~min}$, and the non-specific sites were blocked with bovine serum albumin (BSA, DAKO) for $20 \mathrm{~min}$ at room temperature. For detecting $\mathrm{eMyHC}$, heat-induced antigen retrieval was performed (Tris/EDTA buffer, $\mathrm{pH}$ 8, DAKO) prior to staining the muscle samples. The sections were then incubated overnight at $4{ }^{\circ} \mathrm{C}$ with primary antibody of anti-eMyHC (clone BF-45, mouse, 1:400). The BF-45 monoclonal antibody was obtained from DSHB at the University of Iowa in USA. After thorough washing in PBS, the sections were incubated with biotin-conjugated secondary antibodies (DAKO) at $37{ }^{\circ} \mathrm{C}$ for $20 \mathrm{~min}$. We used a standard peroxidase-based method with DAB (DAKO) to detect the antibody. The sections were dehydrated with ethyl alcohol and coverslipped with mounting medium. The stained sections were imaged using an Olympus BX51 microscope.

\section{Evans blue assay}

Evans blue assay was performed as described previously [18]. Evans blue dye $(10 \mathrm{mg} / \mathrm{ml})$ was dissolved in phosphate buffered saline (PBS). Then, it was filtered sterilely by a $0.2-\mu \mathrm{m}$ pore filter. The Evans blue dye was intraperitoneally injected into the mouse $(0.1 \mathrm{ml} / 10 \mathrm{~g}$ body weight). The mice were killed $24 \mathrm{~h}$ after injection. The quadriceps muscle of these killed mice was prepared and observed under the Olympus Bx51microscope.

\section{Single-fiber analyses}

Single fibers were isolated and fiber size was measured as described previously [19]. The quadriceps muscles were fixed with $4 \%$ paraformaldehyde (PFA) for more than 2 days. Dissected small bundles of fibers were incubated in $40 \% \mathrm{NaOH}$ for $2-3 \mathrm{~h}$ and vigorously shaken. Isolated myofibers were washed in PBS and stained with $10 \mu \mathrm{M}$ DAPI. Images of 40-60 single fibers per animal were captured with the Olympus Bx51 microscope, and fiber diameter was measured by Olympus Element software.

\section{Muscle ATP level}

For the muscle ATP level, we used a luminometric assay with ATP Assay kit (Beyotime) according to the manufacturer's instructions.

\section{Real-time PCR}

The muscles were harvested from ALAS2 transgenic and wild-type (WT) mice and were frozen immediately in liquid nitrogen, and then they were stored frozen at -80 ${ }^{\circ} \mathrm{C}$. For RNA isolation, the tissue was homogenized in Trizol reagent (Invitrogen) and total RNA was prepared according to the manufacturer's protocol. The RNA was reverse transcribed into cDNA by High-Capacity cDNA Reverse Transcription kit (Applied Biosystems). Realtime PCR (RT-PCR) analyses were performed by the ABI 7500 real-time PCR system (Applied Biosystems). The glyceraldehyde-3-phosphate dehydrogenase (GAPD $\mathrm{H})$ expression was used to normalize the expression levels. The relative expression values gained were used to calculate fold change. The primer sequences are listed in Table $1\left(5^{\prime}-3^{\prime}\right)$.

\section{Mitochondrial DNA (mtDNA) content assay}

The muscles were digested and the DNA was isolated using the DNeasy Blood and Tissue kit (QIAGEN). The mtDNA content was quantified by qRT-PCR using a SYBR Green-based detection system by the ABI 7500 real-time PCR system (Applied Biosystems) according to the manufacturer's protocol in a similar way as the previous description [20]. The qRT-PCR primer sequences of mtDNA and nucleus DNA were as follows $\left(5^{\prime}-3^{\prime}\right)$, mtDNA: Forward primer was AAGTCGTAACAAGG TAAGCA, and Reverse primer was ATATTTGTGT AGGGCTAGGG; Nuc.DNA: Forward primer was GGGTATATTTTTGATACCTTCAATGAGTTA, and Reverse primer was TCTGAAACAGTAGGTAGAGACCAAAGC.

\section{Transmission electron microscopy (TEM)}

The muscle blocks were prepared and soaked immediately in $2.5 \%$ glutaraldehyde. After $6-8 \mathrm{~h}$ at $4{ }^{\circ} \mathrm{C}$, they were cut into $1 \mathrm{~mm}$ thick coronal slices. Next, the samples were rinsed with PBS $(0.1 \mathrm{M})$ before being postfixed by osmium tetroxide for 1-2 $\mathrm{h}$. The muscle blocks were dehydrated through a graded series of alcohol and acetone. Subsequently, we used epoxy resin for embedding prior to slicing of the ultra-thin sections. Then, double staining by uranyl acetate and lead citrate was performed. Finally, the images were acquired by a 


\begin{tabular}{|c|c|c|}
\hline & Forward primer & Reverse primer \\
\hline GAPDH & GTTGTCTCCTGCGACTTCA & GGTGGTCCAGGGTTTCTTA \\
\hline MHC & GCCTCCTTCTTCATCTGGTAAC & ATCTCAGCGTCGGAACTCAT \\
\hline Myod1 & AGGACACGACTGCTTTCTTCAC & AGGTTCTGTGGGTTGGAATG \\
\hline myogenin & GCTGTCCTGATGTCCAGAAAAC & GGGTGTTAGCCTTATGTGAATG \\
\hline S6K1 & CACAGCGTGCTTTTACTTGGC & GGTTGTGGCCGCTTCTCATT \\
\hline utrophin & ACGAATTCAGTGACATCATTAAGTCC & ATCCATTTGGTAAAGGTTTTCTTCTG \\
\hline dystrophin & CGATTCAAGAGTTATGCCTTCA & CAGATTTACTTCCGTCTCCATCA \\
\hline Atrogin-1 & CTCTGCTGTGAGTGCCACAT & CAATGAGCCTGGGTACCACT \\
\hline MuRF1 & ACAACCTGTGCCGCAAGTG & AGGACAACCTCGTGCCTACAAG \\
\hline HO-1 & GAAGAACTTTCAGAAGGGTCAG & TCGTCGGAGACGCTTTACATAG \\
\hline UCP3 & GTTTACTGACAACTTCCCCT & CTCCTGAGCCACCATCT \\
\hline
\end{tabular}

transmission electron microscope (JEM-1220, JEOL Ltd, Tokyo, Japan).

\section{Western blotting}

About $20 \mathrm{mg}$ muscle tissue was lysed in RIPA Lysis Buffer (Beyotime) for 10 minutes on ice. RIPA Lysis Buffer is configured with $20 \mathrm{mM}$ Tris PH7.5, $150 \mathrm{mM}$ $\mathrm{NaCl}, 1 \%$ Triton $\mathrm{X}-100,2.5 \mathrm{mM}$ sodium pyrophosphate, $1 \mathrm{mM}$ EDTA, $1 \% \mathrm{Na}_{3} \mathrm{VO}_{4}, 0.5 \mu \mathrm{g} / \mathrm{ml}$ leupeptin, and 1 $\mathrm{mM}$ phenyl methane sulfonyl fluoride (PMSF). The lysate homogenate was centrifuged at $12,000 \times g$ at $4{ }^{\circ} \mathrm{C}$ for $5 \mathrm{~min}$. The protein concentration was measured with the DC Protein Assay kit (Bio-Rad Laboratories). Protein samples were boiled for $10 \mathrm{~min}$ in the presence of $4 \times$ Loading Dye. Equal amounts of total proteins $(25 \mu \mathrm{g})$ were loaded on a $12 \%$ SDS-polyacrylamide gel for electrophoresis followed by a transfer to PVDF membranes (Millipore) at $70 \mathrm{~V}$ for $1 \mathrm{~h}$. The membranes were blocked with $5 \%$ non-fat powdered milk in PBS (10 mM, $\mathrm{pH}$ 7.4) for $1 \mathrm{~h}$ at $4{ }^{\circ} \mathrm{C}$. The blot was incubated with the primary antibody (GAPDH, 1:2000, Cell Signaling Technology, HO-1, Santa Cruz Biotechnology) overnight at $4{ }^{\circ} \mathrm{C}$. The membrane was washed three times by PBST, followed by incubation with the appropriate secondary antibody. The signal was detected by an Enzymatic Chemiluminescence (ECL) kit (Applygen).

\section{Statistics}

All quantitative data are expressed as means \pm SD. Statistical analysis was performed using either Student's $t$ test (two groups) or one-way analysis of variance (more than two groups), followed by Bonferroni post hoc test. Differences were considered significant at $P<0.05$.

\section{Results}

Reduction of forelimb muscle grip strength in ALAS2 transgenic mice

As muscle weakness is a clinical manifestation of porphyria [18, 21, 22], we measured the forelimb muscle grip strength by the automated grip strength meter. Interestingly, we found that ALAS2 transgenic (Tg) mice had reduced forelimb muscle strength compared with the age-matched WT littermates (Fig. 1). The data strongly suggest that muscle weakness is present in ALAS2 transgenic ( $\mathrm{Tg}$ ) mice.

\section{Loss of muscle mass in ALAS2 transgenic mice}

$\mathrm{Tg}$ mice were smaller and thinner than the age-matched WT littermates (data not shown). On visual analysis, overall loss of hindlimb muscle mass was clearly evident in Tg mice (Fig. 2a). The wet weight of the quadriceps femoris was approximately half of that in the agematched WT littermates, and this finding was similar to that in the gastrocnemius muscle (Fig. 2b). As Tg mice were smaller and thinner, we normalize the wet weight of the quadriceps femoris mass by the body weight. The results showed that the muscle mass percentage in $\mathrm{Tg}$ mice was lower than that in WT mice (Fig. 2c). The myosin heavy chain (MHC) mRNA expression was also measured. We found the MHC mRNA level in Tg mice was decreased compared with that in WT mice (Fig. 2d). The data indicated muscle mass loss in Tg mice.

\section{Muscle atrophy in ALAS2 transgenic mice}

To determine the cause of loss of muscle mass, HEstained transverse sections of the quadriceps femoris from age-matched Tg mice and WT mice were 


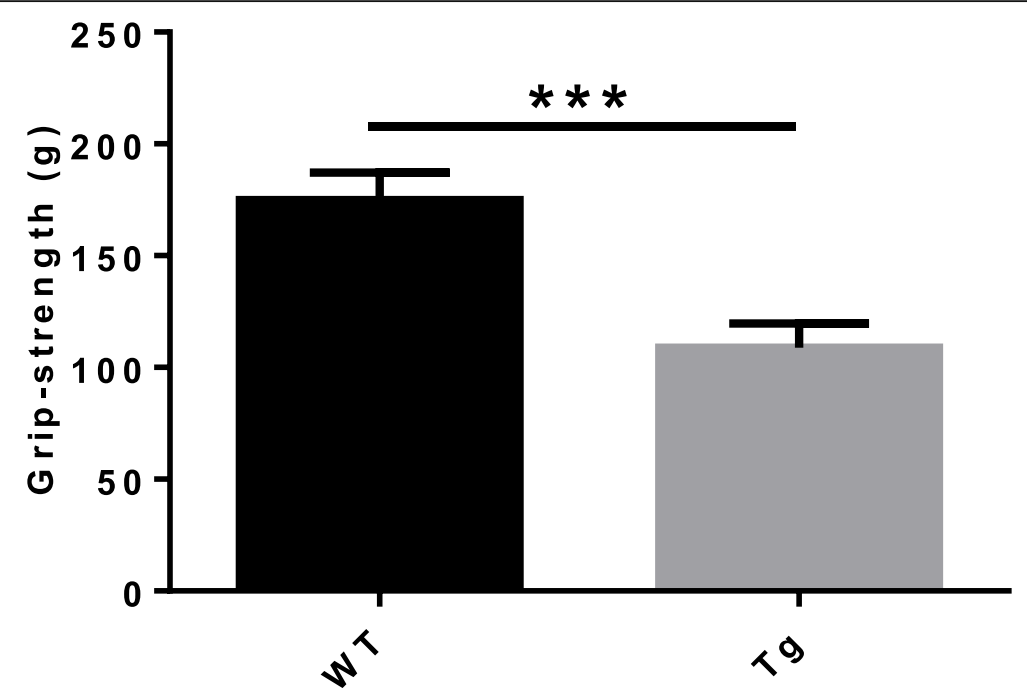

Fig. 1 Reduced forelimb muscle grip strength in ALAS2 transgenic mice. Grip strength in ALAS2 transgenic mice $(n=9)$ and WT mice $(n=8)$. Values are means \pm SD. ${ }^{*} P<0.05$; ${ }^{* *} P<0.01$; ${ }^{* *} P<0.001$

compared. A high number of muscle fibers with centrally located nuclei was found in Tg mice, a primary pathological sign of muscular dystrophy [23], but not in WT mice (Fig. 3a). Moreover, to detect the regeneration of the quadriceps in $\mathrm{Tg}$ mice, re-expression of eMyHC were compared by immunostaining for quadriceps cross section from age-matched Tg mice and WT mice at 6 months old. Re-expression of eMyHC was only showed in the quadriceps of Tg mice, but not in WT mice (Fig. 3b), indicating that the central nucleation determined in $\mathrm{Tg}$

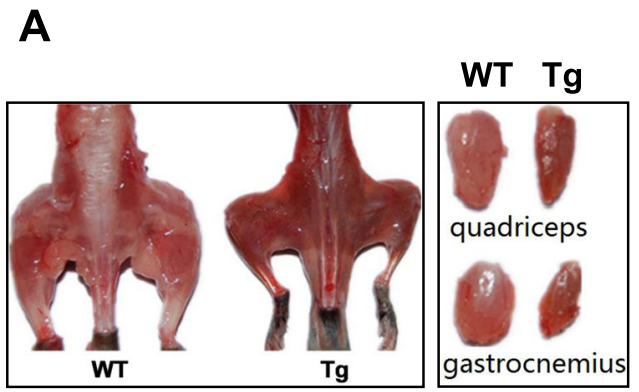

C

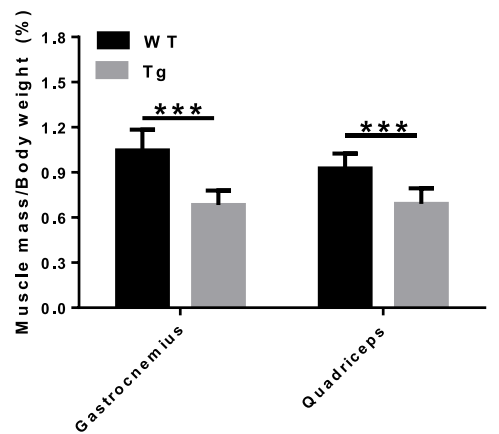

B

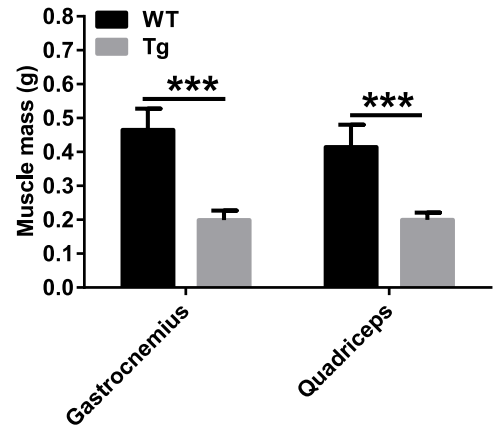

D

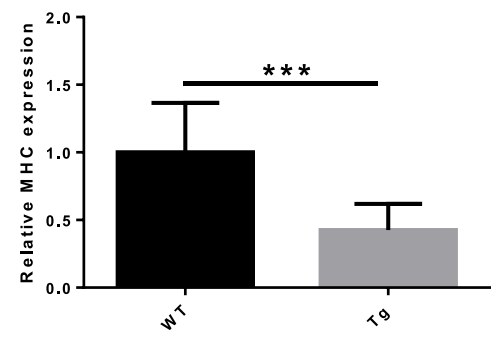

Fig. 2 Loss of muscle mass in the ALAS2 transgenic mice. a Left panel: gross morphology of skinned hindlimb muscles of ALAS2 transgenic mice and WT mice. Right panel: comparison of individual muscles. b Comparison of changes in wet weight of individual muscles mass $(n=6-7)$. c Comparison of in wet weight of individual muscles mass normalized to body weight ( $n=6-7)$. $\mathbf{d}$ The MHC mRNA expression ( $n=6-7)$. Values are means $\pm S D . * P<0.05 ; * P<0.01 ; * * P<0.001$ 


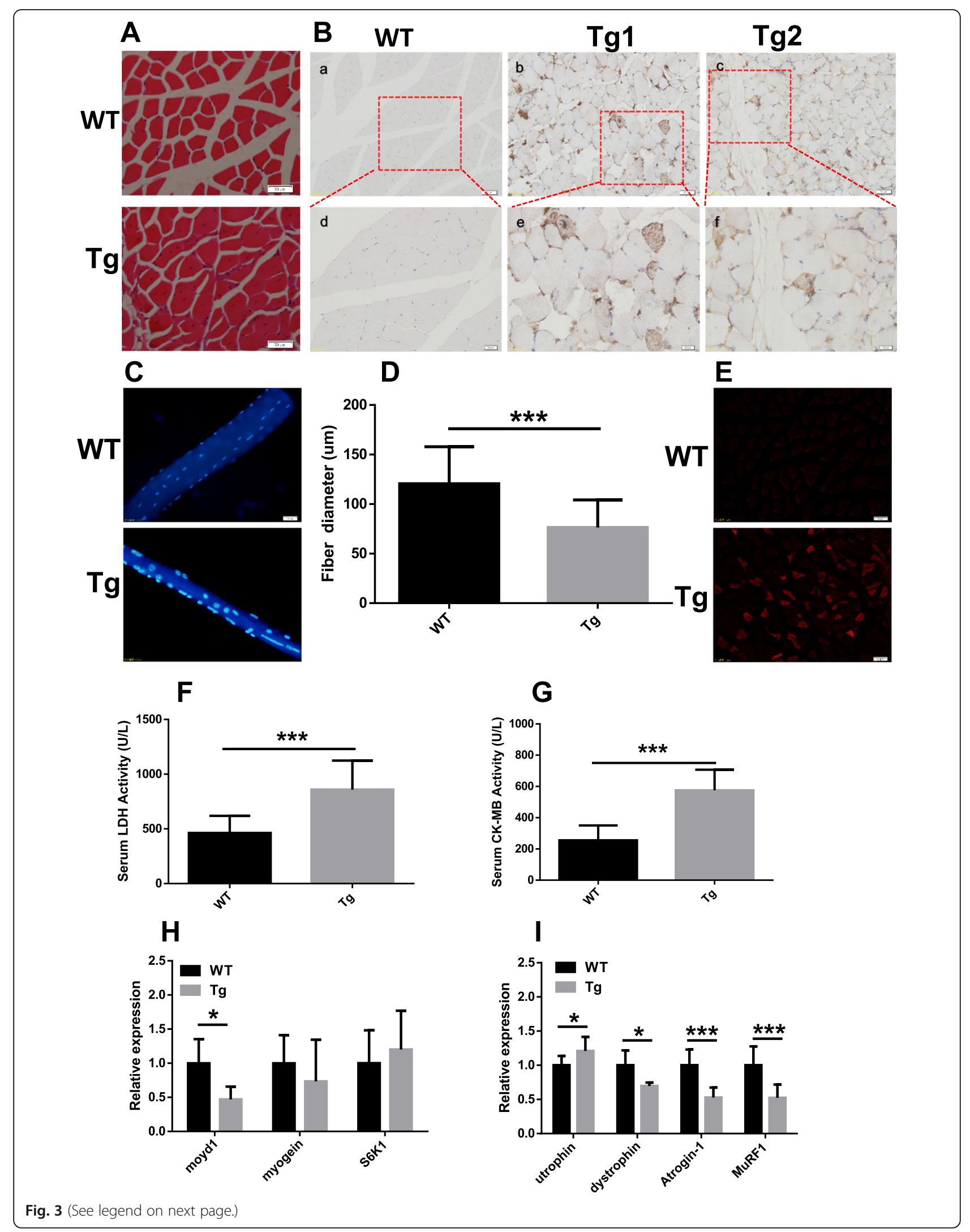




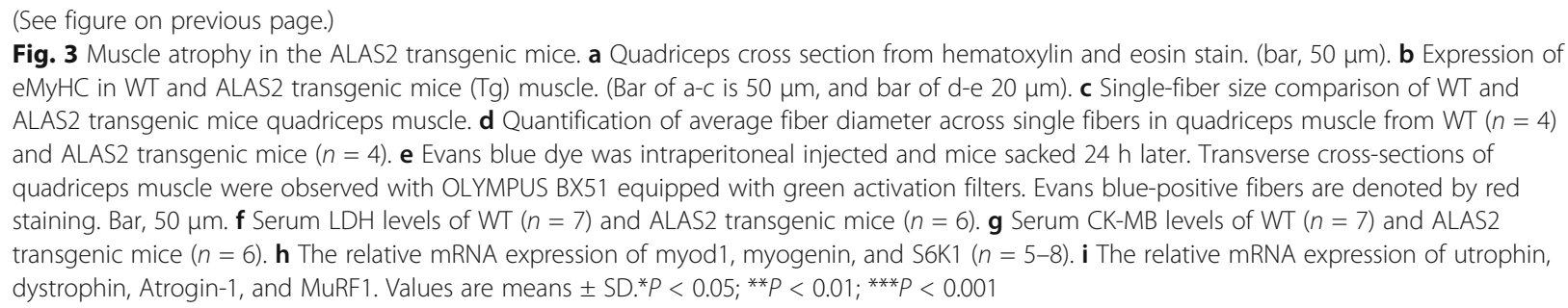

mice muscles resulted from muscle regeneration $[24,25]$. With respect to single-fiber analyses [19, 26], the average diameter of single fibers isolated from the muscle of $\mathrm{Tg}$ mice was smaller than that isolated from the muscle of WT mice (Fig. 3c, d). In addition, to examine leakage into the muscle fiber, Evans blue assay was employed [18, 27]. The fluorescent dye accumulated in the interior of dystrophied muscle fibers in Tg mice (Fig. 3e). We showed that the myocyte membrane was damaged in dystrophied muscle of Tg mice. Moreover, we detected the activities of serum CK, CK-MB, and $\mathrm{LDH}$, and we found the elevation of the activity of serum CK-MB and LDH in Tg mice (Fig. $3 f, g)$. We analyzed the expression of the genes, and we found that the expression levels of MyoD1, dystrophin, Atrogin-1, and MuRF1 were decreased, but the expression level of utrophin was increased. There was no difference in myogenin and S6K1 in Tg mice compared with WT mice (Fig. 3h, i). Albertyn $\mathrm{CH}$ et al. also described that acute intermittent porphyria presenting as progressive muscular atrophy in a 23-year-old black South African $\operatorname{man}[12]$.

\section{Mitochondrial dysfunction in the muscle of ALAS2 transgenic mice}

To test whether muscle dystrophy in $\mathrm{Tg}$ mice was affected by mitochondrial damage, we examined the ultrastructure of muscle fibers using a transmission electron microscope. Mitochondrial swelling was found in muscles of Tg mice (Fig. 4a, right), but not in muscles of WT mice (Fig. 4a, left). Then we compared the mtDNA content, uncoupling protein 3 (UCP-3) mRNA expression, and ATP production in the hind limb muscles of Tg mice and age-matched WT mice. The mtDNA content quantified by qRT-PCR [20] was significantly reduced in the gastrocnemius muscle of Tg mice (Fig. 4b). The muscle UCP-3 mRNA expression was decreased in Tg mice (Fig. 4c). ATP production in the gastrocnemius muscle of $\mathrm{Tg}$ mice was decreased to $21 \%$ of the level in age-matched WT mice (Fig. 4d). Interestingly, increased expression levels of SOD1 mRNA, HO-1 mRNA, and HO-1 protein showed that SOD1 and HO-1 were induced in the muscle of Tg mice (Fig. 4e, f). Above all, mitochondrial dysfunction and loss were present in the muscle of $\mathrm{Tg}$ mice. It was reported that mitochondrial energetic failure played an important role in the expression of acute intermittent porphyria (AIP) [28].

\section{Discussion}

ALAS2-overexpressing Tg mice were developed to investigate the mechanism of porphyria. The expression of ALAS2 was increased in Tg mice [29]. Tg mice showed obvious muscular atrophy, which is also a clinical characteristic of porphyria. Therefore, we explored the mechanism of muscular atrophy in Tg mice. Firstly, we found that $\mathrm{Tg}$ mice experienced a decrease in muscle mass and grip strength of the forelimb muscles. Secondly, increased activities of serum CK-MB and LDH, increased central nuclear fiber and Evans blue positive fiber and decreased single-fiber diameter confirmed muscle atrophy in Tg mice. In addition, Re-expression of eMyHC was only showed in the quadriceps of $\mathrm{Tg}$ mice, but not in WT mice, indicating that the central nucleation determined in $\mathrm{Tg}$ mice muscles resulted from muscle regeneration. Furthermore, the expression levels of MyoD1, S6K1 (anabolic factor), atrogin1, and MuRF1 (catabolic factor) were determined. Finally, muscle mitochondrial dysfunction in ALAS2 Tg mice was detected based on mitochondrial swelling, decline in ATP production and mtDNA content, and downregulation of UCP3 mRNA expression.

We found that the muscle grip strength of forelimbs of Tg mice was decreased. Since muscle mass determines the skeletal muscle strength [30], the loss of muscle strength in Tg mice may be caused by the loss of muscle mass. The diameter of single fibers of $\mathrm{Tg}$ mice was smaller than that of WT mice, and thinner fiber indicated less muscle mass. MHC is an important part of the sarcomere [31]. We found that the mRNA level of MHC in Tg mice was decreased, which meant that the loss of muscle mass may be caused by the decrease in MHC content. In addition to the decreased muscle mass of atrophic muscles, a large number of muscle fibers with centrally located nucleus were observed in Tg mice, which is a sign of muscle fiber regeneration [32,33]. We also found that the re-expression of eMyHC was only showed in the quadriceps of Tg mice, but not in WT mice, confirming that the central nucleation determined in Tg mice muscles resulted from muscle regeneration. 

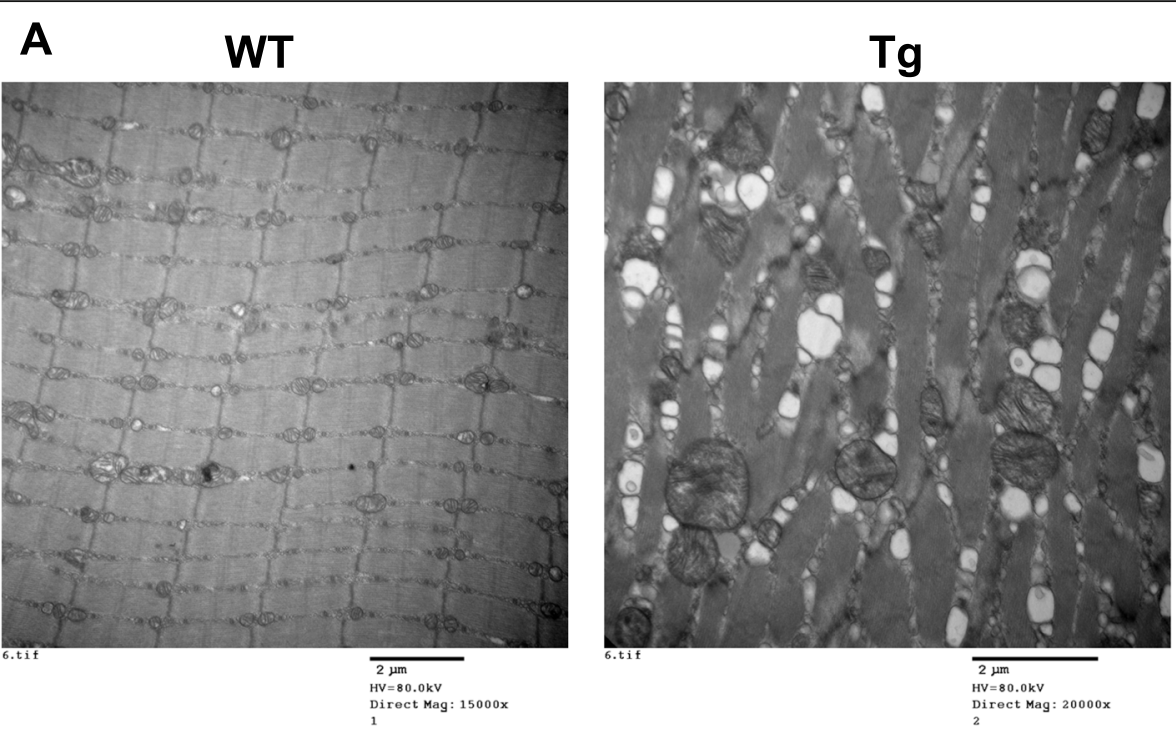

B

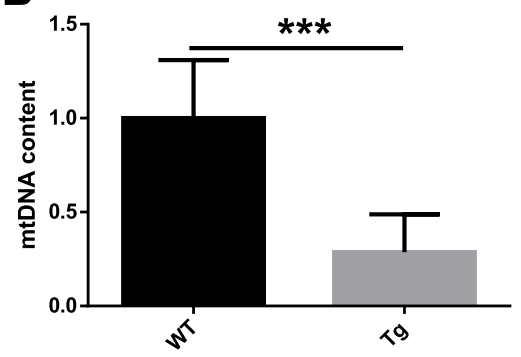

D

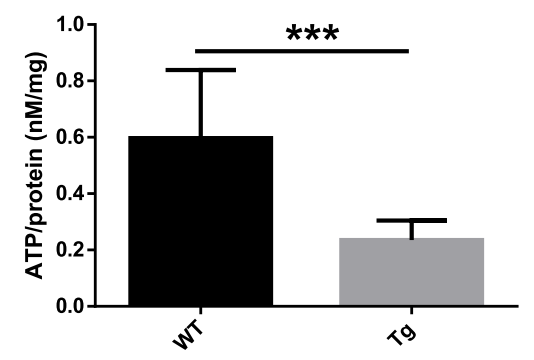

F

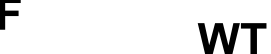

C

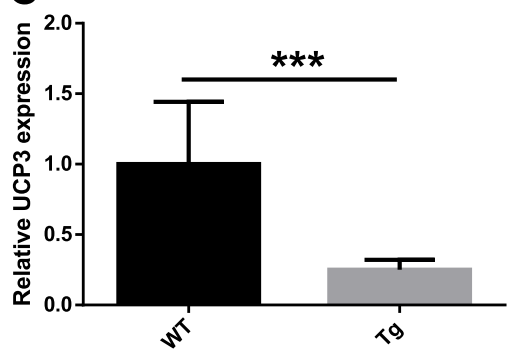

E

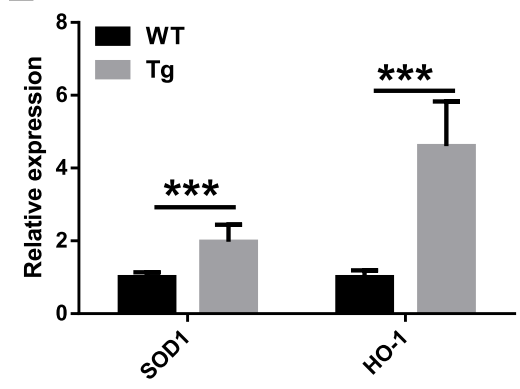

$\mathrm{Tg}$

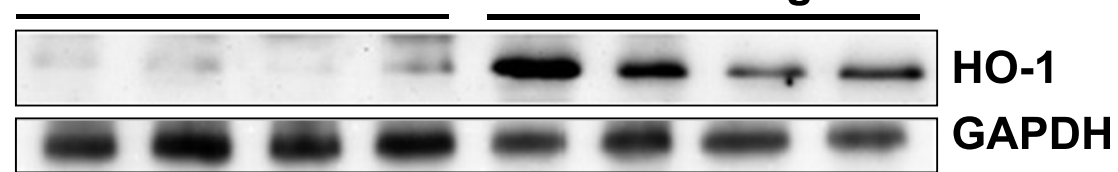

Fig. 4 Mitochondrial dysfunction in the ALAS2 transgenic mice muscle. a TEM images of gastrocnemius of WT and ALAS2 transgenic mice. Bars, $2 \mu \mathrm{m} . \mathbf{b} \mathrm{mtDNA}$ content in gastrocnemius of WT $(n=8)$ and ALAS2 transgenic mice $(n=7)$. $\mathbf{c}$ UCP3 expression in quadriceps of WT $(n=8)$ and ALAS2 transgenic mice $(n=7)$. $\mathbf{d}$ ATP production in gastrocnemius of WT $(n=8)$ and ALAS2 transgenic mice $(n=8)$. e The SOD1 and HO-1 mRNA expression $(n=5-8)$. f The HO-1 protein expression $(n=4)$. Values are means \pm SD. ${ }^{*} P<0.05 ;{ }^{*} P<0.01 ;{ }^{* *} P<0.001$

The Evans blue dye could enter into the myocyte through the damaged cytomembrane and get accumulated in the myocyte, and thus, Evans blue dye was used to identify damaged skeletal myofibers [27, 34, 35]. Accumulation of Evans blue dye in the myocyte of $\mathrm{Tg}$ mice suggested that the myocyte membrane was damaged in $\mathrm{Tg}$ mice. Also, increased activities of serum LDH and CK-MB indicated that the muscular membrane of $\mathrm{Tg}$ mice was damaged [36-38]. The expression of MyoD1 was decreased in 
Tg mice compared with WT mice. Since muscle regeneration has been reported to be delayed in MyoD (-/-) mice [39], decreased MyoD1 might cause a disturbance in the regeneration in $\mathrm{Tg}$ mice.

The expression of utrophin was increased and that of dystrophin was decreased in $\mathrm{Tg}$ mice compared with WT mice, which was similar to that in other dystrophy reports $[33,40]$. MAFbx and MuRF1 belong to the ubiquitin proteasome pathway, which plays a critical role in the intracellular protein degradation of skeletal muscle [41]. Upregulation of atrophy-related genes atrogin-1 (MAFbX) and MuRF1 in skeletal muscle atrophy has been reported previously [42, 43]. However, atrogin-1 and MuRF1 were downregulated in aging-related loss of skeletal muscle [44] and in mTOR-mice [33], and here, we also found that atrogin-1 and MuRF1 levels were decreased in Tg mice. Inhibition of MuRF1 is sufficient to maintain the MHC [44]. However, MHC in Tg mice was decreased, which indicated that the loss of muscle mass in Tg mice was not related to activation of the ubiquitin proteasome pathway. A previous study showed that chronic spinal cord-injured patients with severe atrophy of the quadriceps muscles showed a reduction in atrogin-1 and MuRF1, which suggested an internal mechanism aimed at reducing the further loss of muscle proteins $[45,46]$. The reduction of atrogin- 1 and MuRF1 in $\mathrm{Tg}$ mice may also be a protective attempt to reduce further muscle wasting in muscle atrophy.

Mitochondrial dysfunction is a hallmark trait that occurs during prolonged muscle inactivity in both animals and humans. Mitochondrial fission and remodeling contribute to muscle atrophy [47]. Increased superoxide in vivo accelerates age-associated muscle atrophy through mitochondrial dysfunction [19]. Mitochondria play an important role in muscle atrophy $[19,47,48]$. It has been reported that ALA-generated oxidant promotes dysfunction and swelling of the isolated rat liver mitochondria [7]. Similarly, mitochondrial swelling and mitochondrial cristae reduction were shown in muscles of $\mathrm{Tg}$ mice. $\mathrm{As} \mathrm{Tg}$ mice have high expression of ALAS2 [29] and accumulation of ALA in the muscles (data not shown), mitochondrial damage in the muscle of $\mathrm{Tg}$ mice is most likely to be induced by ALA. There is an increase of SOD-1 in the brain, muscle, and liver of chronic ALA-treated rats [8], and thus, we speculate that SOD-1 and HO-1 are induced by ALA in Tg mice. Increasing of anti-oxidant enzymes in $\mathrm{Tg}$ mice indicated oxidant existence. As excessive free radicals accelerate muscle proteolysis [12, 49], the prooxidizing nature of ALA [50] may lead to the loss of muscle mass. Previous studies have indicated that exercise induced up-regulation of UCP-3 and downregulation of UCP-3 would damage the muscles [51, 52]. Decreased mtDNA content and UCP-3 expression suggested that the mitochondrial loss in $\mathrm{Tg}$ mice was correlated with mitochondrial damage. A decrease in the ATP production was observed in Tg mice, which was probably induced by mitochondrial damage and loss. The pCAGGS expression vector can drive EGFP expression in all tissues, except erythrocytes and hair in mice, particularly higher in the muscle [53]. Also, Tg mice have ubiquitous overexpression of ALAS-2 in all tissues and higher expression of ALAS-2 in the muscle. Moreover, the accumulation of ALA is much higher in Tg mice than in WT mice. Because ALA is synthesized in the mitochondria and ALA is a putative endogenous source of ROS [7], ALA might damage the mitochondria of muscle in Tg mice.

Porphyrias are a group of eight metabolic disorders of the heme biosynthesis pathway [7]. Every porphyria is caused by abnormal function of a separate enzymatic step, resulting in a specific accumulation of heme precursors, including ALA, PBG, and porphyrins. In some cases, muscle atrophy was present in porphyria; however, the underlying mechanism is still unknown. ALAS2-overexpressing $\mathrm{Tg}$ mice also show accumulation of ALA, thus it may be a new model of porphyria. In the future, we will further verify whether ALAS2overexpressing $\mathrm{Tg}$ mice can be used as a porphyria model, and we will use this model to investigate the relationship of mitochondrial dysfunction and porphyriarelated muscle weakness.

\section{Conclusion}

Muscle weakness in ALAS2-overexpressing mice is related to muscle mitochondrial dysfunction induced by the accumulation of ALA.

\section{Abbreviations}

ALAS2: Delta-aminolevulinate synthase 2; ALA: Delta-aminolevulinic acid; Tg mice: Transgenic mice; WT mice: Wild-type mice; ATP: Adenosine triphosphate; HE: Hematoxylin and eosin; ROS: Reactive oxygen species; EPP: Erythropoietic protoporphyria; XLPP: X-linked protoporphyria; mtDNA: Mitochondrial DNA; LDH: Lactate dehydrogenase ; CK: Creatine kinase; CK-MB: Creatine kinase-MB; GAPDH: Glyceraldehyde-3-phosphate dehydrogenase; TEM: Transmission electron microscopy

\section{Supplementary Information}

The online version contains supplementary material available at https://doi. org/10.1186/s13395-021-00263-8.

Additional file 1 : Figs. 1 Overexpresion ALAS-2 in in mouse myoblasts (C2C12). A, The relative mRNA expression of ALAS-2. B, The relative mRNA expression of myod1, myogein and S6K1. C, The relative mRNA expression of utrophin, dystrophin, Atrogin-1 and MuRF1. Values are means \pm SD. ${ }^{*} P<0.05$; ${ }^{* *} P<0.01 ;{ }^{* * *} P<0.001$.

\section{Acknowledgements}

Not applicable.

\section{Authors' contributions}

$X G, Y H$, and $R H$ designed the study. YP, JL, DL, SZ, SL, DW, XW, ZZ, XW, and CS performed experiments and analyzed data. YP and $\mathrm{RH}$ wrote the manuscript. All authors read and approved the final manuscript. 


\section{Funding}

This work was supported by Natural Science Foundation of China (81773165, 81671255), Hunan Province Science Fund for Distinguished Young Scholars (2018J 1021), the Natural Science Foundation of Hunan Province (2020JJ5013), and Chinese Scholarship Council Fund for the Visiting Scholars (No. 201908230108).

\section{Availability of data and materials}

All the data and material could be traced from the paper or can be requested from the corresponding author.

\section{Declarations}

\section{Ethics approval and consent to participate}

The study was approved by the local Ethic Committee.

\section{Competing interests}

The authors declare that they have no competing interests.

\section{Author details}

${ }^{1}$ Department of Biochemistry and Molecular Biology, Harbin Medical University, Harbin 150086, China. ${ }^{2}$ Institute of Translational Medicine, National and Local Joint Engineering Laboratory of High-through Molecular Diagnostic Technology, the First People's Hospital of Chenzhou, The First Affiliated Hospital of Xiangnan University, Chenzhou 423000, China. ${ }^{3}$ Heilongjiang Academy of Medical Sciences, Harbin 150086, China. ${ }^{4}$ Key Laboratory of Preservation of Human Genetic Resources and Disease Control in China (Harbin Medical University), Ministry of Education, Beijing 150086, China. ${ }^{5}$ Department of Clinical Pharmacology, Xiangya Hospital, Central South University, Changsha 410078, China.

\section{Received: 15 January 2020 Accepted: 2 March 2021}

Published online: 30 March 2021

\section{References}

1. Tchaikovskii V, Desnick RJ, Bishop DF. Molecular expression, characterization and mechanism of ALAS2 gain-of-function mutants. Mol Med. 2019;25(1):4.

2. Riddle RD, Yamamoto M, Engel JD. Expression of delta-aminolevulinate synthase in avian cells: separate genes encode erythroid-specific and nonspecific isozymes. Proc Natl Acad Sci U S A. 1989;86(3):792-6.

3. Yamamoto M, Kure S, Engel JD, Hiraga K. Structure, turnover, and hememediated suppression of the level of mRNA encoding rat liver deltaaminolevulinate synthase. J Biol Chem. 1988;263(31):15973-9.

4. Kolluri S, Sadlon TJ, May BK, Bonkovsky HL. Haem repression of the housekeeping 5-aminolaevulinic acid synthase gene in the hepatoma cell line LMH. Biochem J. 2005;392(Pt 1):173-80.

5. Peoc'h K, Nicolas G, Schmitt C, Mirmiran A, Daher R, Lefebvre T, Gouya L, Karim Z, Puy H. Regulation and tissue-specific expression of deltaaminolevulinic acid synthases in non-syndromic sideroblastic anemias and porphyrias. Mol Genet Metab. 2019;128(3):190-7.

6. Smith SJ, Cox TM. Translational control of erythroid delta-aminolevulinate synthase in immature human erythroid cells by heme. Cell Mol Biol. 1997; 43(1):103-14.

7. Hermes-Lima M, Castilho RF, Valle VG, Bechara EJ, Vercesi AE. Calciumdependent mitochondrial oxidative damage promoted by 5 -aminolevulinic acid. Biochim Biophys Acta. 1992;1180(2):201-6.

8. Pereira B, Curi R, Kokubun E, Bechara EJ. 5-aminolevulinic acid-induced alterations of oxidative metabolism in sedentary and exercise-trained rats. J Appl Physiol. 1992;72(1):226-30.

9. Yamada T, Ivarsson N, Hernandez A, Fahlstrom A, Cheng AJ, Zhang SJ, Bruton JD, Ulfhake B, Westerblad H. Impaired mitochondrial respiration and decreased fatigue resistance followed by severe muscle weakness in skeletal muscle of mitochondrial DNA mutator mice. J Physiol. 2012; 590(23):6187-97.

10. Powers SK, Wiggs MP, Duarte JA, Zergeroglu AM, Demirel HA. Mitochondrial signaling contributes to disuse muscle atrophy. Am J Physiol Endocrinol Metab. 2012;303(1):E31-9.

11. Peker N, Donipadi V, Sharma M, McFarlane C, Kambadur R. Loss of Parkin impairs mitochondrial function and leads to muscle atrophy. Am J Physiol Cell Physiol. 2018;315(2):C164-85.
12. Albertyn $\mathrm{CH}$, Sonderup $\mathrm{M}$, Bryer $\mathrm{A}$, Corrigall $\mathrm{A}$, Meissner $\mathrm{P}$, Heckmann JM. Acute intermittent porphyria presenting as progressive muscular atrophy in a young black man. S Afr Med J. 2014;104(4):283-5.

13. Puy H, Gouya L, Deybach JC. Porphyrias. Lancet. 2010;375(9718):924-37.

14. Barman-Aksozen J, Minder El, Schubiger C, Biolcati G, Schneider-Yin X. In ferrochelatase-deficient protoporphyria patients, ALAS2 expression is enhanced and erythrocytic protoporphyrin concentration correlates with iron availability. Blood Cells Mol Dis. 2015;54(1):71-7.

15. Manceau H, Gouya L, Puy H. Acute hepatic and erythropoietic porphyrias: from ALA synthases 1 and 2 to new molecular bases and treatments. Curr Opin Hematol. 2017;24(3):198-207.

16. To-Figueras J, Ducamp S, Clayton J, Badenas C, Delaby C, Ged C, Lyoumi S, Gouya L, de Verneuil H, Beaumont C, et al. ALAS2 acts as a modifier gene in patients with congenital erythropoietic porphyria. Blood. 2011;118(6):144351.

17. Windahl SH, Andersson N, Borjesson AE, Swanson C, Svensson J, MoverareSkrtic S, Sjogren K, Shao R, Lagerquist MK, Ohlsson C. Reduced bone mass and muscle strength in male 5alpha-reductase type 1 inactivated mice. PLoS One. 2011;6(6):e21402.

18. Crosbie RH, Straub V, Yun HY, Lee JC, Rafael JA, Chamberlain JS, Dawson VL, Dawson TM. Campbell KP: mdx muscle pathology is independent of nNOS perturbation. Hum Mol Genet. 1998;7(5):823-9.

19. Jang YC, Lustgarten MS, Liu Y, Muller FL, Bhattacharya A, Liang H, Salmon $A B$, Brooks SV, Larkin L, Hayworth CR, et al. Increased superoxide in vivo accelerates age-associated muscle atrophy through mitochondrial dysfunction and neuromuscular junction degeneration. FASEB J. 2010;24(5): 1376-90.

20. Viader A, Golden JP, Baloh RH, Schmidt RE, Hunter DA, Milbrandt J. Schwann cell mitochondrial metabolism supports long-term axonal survival and peripheral nerve function. J Neurosci. 2011;31(28):10128-40.

21. Cavanagh JB, Mellick RS. On the Nature of the Peripheral Nerve Lesions Associated with Acute Intermittent Porphyria. J Neurol Neurosurg Psychiatry. 1965;28:320-7.

22. Moorhead PJ, Cooper DJ, Timperley WR. Progressive peripheral neuropathy in patient with primary hyperoxaluria. Br Med J. 1975;2(5966):312-3.

23. Wang B, Li J, Xiao X. Adeno-associated virus vector carrying human minidystrophin genes effectively ameliorates muscular dystrophy in mdx mouse model. Proc Natl Acad Sci U S A. 2000;97(25):13714-9.

24. Schiaffino S, Rossi AC, Smerdu V, Leinwand LA, Reggiani C. Developmental myosins: expression patterns and functional significance. Skelet Muscle. 2015;5:22.

25. Silva WJ, Graca FA, Cruz A, Silvestre JG, Labeit S, Miyabara EH, Yan CYI, Wang DZ. Moriscot AS: miR-29c improves skeletal muscle mass and function throughout myocyte proliferation and differentiation and by repressing atrophy-related genes. Acta Physiol. 2019;226(4):e13278.

26. Wada Kl, Takahashi H, Katsuta S, Soya H. No decrease in myonuclear number after long-term denervation in mature mice. Am J Physiol Cell Physiol. 2002;283(2):C484-8.

27. Matsuda R, Nishikawa A, Tanaka H. Visualization of dystrophic muscle fibers in mdx mouse by vital staining with Evans blue: evidence of apoptosis in dystrophin-deficient muscle. J Biochem. 1995;118(5):959-64.

28. Homedan C, Schmitt C, Laafi J, Gueguen N, Desquiret-Dumas V, Lenglet H, Karim Z, Gouya L, Deybach JC, Simard G, et al. Mitochondrial energetic defects in muscle and brain of a Hmbs-/- mouse model of acute intermittent porphyria. Hum Mol Genet. 2015;24(17):5015-23.

29. Huang H, Wang W, Zou J, Liu Z, Zhou Z, Nakajima O, Zhang L, Luo J, Li M, He Q, et al. Over-expression 5-aminolevulinic acid synthase 2 in nonerythroid cell may causes protoporphyrin IX accumulation. Photodiagnosis Photodyn Ther. 2017;17:22-8.

30. Frontera WR, Hughes VA, Lutz KJ, Evans WJ. A cross-sectional study of muscle strength and mass in 45- to 78-yr-old men and women. J Appl Physiol. 1991;71(2):644-50.

31. Derbre F, Ferrando B, Gomez-Cabrera MC, Sanchis-Gomar F, Martinez-Bello VE, Olaso-Gonzalez G, Diaz A, Gratas-Delamarche A, Cerda M, Vina J. Inhibition of xanthine oxidase by allopurinol prevents skeletal muscle atrophy: role of p38 MAPKinase and E3 ubiquitin ligases. PLoS One. 2012; 7(10):e46668.

32. Handschin C, Chin S, Li P, Liu F, Maratos-Flier E, Lebrasseur NK, Yan Z, Spiegelman BM. Skeletal muscle fiber-type switching, exercise intolerance, and myopathy in PGC-1alpha muscle-specific knock-out animals. J Biol Chem. 2007;282(41):30014-21. 
33. Risson V, Mazelin L, Roceri M, Sanchez H, Moncollin V, Corneloup C, RichardBulteau H, Vignaud A, Baas D, Defour A, et al. Muscle inactivation of mTOR causes metabolic and dystrophin defects leading to severe myopathy. J Cell Biol. 2009;187(6):859-74.

34. Brussee V, Tardif F, Tremblay JP. Muscle fibers of mdx mice are more vulnerable to exercise than those of normal mice. Neuromuscul Disord. 1997;7(8):487-92.

35. Hamer PW, McGeachie JM, Davies MJ, Grounds MD. Evans Blue Dye as an in vivo marker of myofibre damage: optimising parameters for detecting initial myofibre membrane permeability. J Anat. 2002;200(Pt 1):69-79.

36. Keshgegian AA, Feinberg NV. Serum creatine kinase MB isoenzyme in chronic muscle disease. Clin Chem. 1984;30(4):575-8.

37. Apple FS, McGue MK. Serum enzyme changes during marathon training Am J Clin Pathol. 1983;79(6):716-9.

38. Siegel AJ, Silverman LM, Evans WJ. Elevated skeletal muscle creatine kinase MB isoenzyme levels in marathon runners. Jama. 1983;250(20):2835-7.

39. White JD, Scaffidi A, Davies M, McGeachie J, Rudnicki MA, Grounds MD. Myotube formation is delayed but not prevented in MyoD-deficient skeletal muscle: studies in regenerating whole muscle grafts of adult mice. J Histochem Cytochem. 2000;48(11):1531-44.

40. Cifuentes-Diaz C, Frugier T, Tiziano FD, Lacene E, Roblot N, Joshi V, Moreau $\mathrm{MH}$, Melki J. Deletion of murine SMN exon 7 directed to skeletal muscle leads to severe muscular dystrophy. J Cell Biol. 2001;152(5):1107-14.

41. Lecker SH, Solomon V, Mitch WE, Goldberg AL. Muscle protein breakdown and the critical role of the ubiquitin-proteasome pathway in normal and disease states. J Nutr. 1999:129(1S Suppl):227S-375

42. Lagirand-Cantaloube J, Offner N, Csibi A, Leibovitch MP, Batonnet-Pichon S, Tintignac LA, Segura CT, Leibovitch SA. The initiation factor elF3-f is a major target for atrogin1/MAFbx function in skeletal muscle atrophy. EMBO J. 2008;27(8):1266-76.

43. Stitt TN, Drujan D, Clarke BA, Panaro F, Timofeyva Y, Kline WO, Gonzalez M, Yancopoulos GD, Glass DJ. The IGF-1/PI3K/Akt pathway prevents expression of muscle atrophy-induced ubiquitin ligases by inhibiting FOXO transcription factors. Mol Cell. 2004;14(3):395-403.

44. Edstrom E, Altun M, Hagglund M, Ulfhake B. Atrogin-1/MAFbx and MuRF1 are downregulated in aging-related loss of skeletal muscle. J Gerontol A Biol Sci Med Sci. 2006;61(7):663-74.

45. Foletta $V C$, White $L$, Larsen $A E$, Leger B, Russell AP. The role and regulation of MAFbx/atrogin-1 and MuRF1 in skeletal muscle atrophy. Pflugers Arch. 2011;461(3):325-35.

46. Leger B, Senese R, Al-Khodairy AW, Deriaz O, Gobelet C, Giacobino JP, Russell AP. Atrogin-1, MuRF1, and FoXO, as well as phosphorylated GSK3beta and 4E-BP1 are reduced in skeletal muscle of chronic spinal cordinjured patients. Muscle Nerve. 2009;40(1):69-78.

47. Romanello V, Guadagnin E, Gomes L, Roder I, Sandri C, Petersen Y, Milan G, Masiero E, Del Piccolo P, Foretz M, et al. Mitochondrial fission and remodelling contributes to muscle atrophy. EMBO J. 2010;29(10):1774-85.

48. Chen $\mathrm{H}$, Vermulst $M$, Wang YE, Chomyn A, Prolla TA, McCaffery JM, Chan DC. Mitochondrial fusion is required for mtDNA stability in skeletal muscle and tolerance of mtDNA mutations. Cell. 2010;141(2):280-9.

49. Romanello V, Sandri M. Mitochondrial quality control and muscle mass maintenance. Front Physiol. 2015;6:422.

50. Bechara EJ, Dutra F, Cardoso VE, Sartori A, Olympio KP, Penatti CA, Adhikari A, Assuncao NA. The dual face of endogenous alpha-aminoketones: prooxidizing metabolic weapons. Comp Biochem Physiol Toxicol Pharmacol. 2007;146(1-2):88-110.

51. Jones TE, Baar K, Ojuka E, Chen M, Holloszy JO. Exercise induces an increase in muscle UCP3 as a component of the increase in mitochondrial biogenesis. Am J Physiol Endocrinol Metab. 2003;284(1):E96-101.

52. Tsuboyama-Kasaoka N, Tsunoda N, Maruyama K, Takahashi M, Kim H, Ikemoto S, Ezaki O. Up-regulation of uncoupling protein 3 (UCP3) mRNA by exercise training and down-regulation of UCP3 by denervation in skeletal muscles. Biochem Biophys Res Commun. 1998;247(2):498-503.

53. Okabe M, Ikawa M, Kominami K, Nakanishi T. Nishimune Y: 'Green mice' as a source of ubiquitous green cells. FEBS Lett. 1997;407(3):313-9.

\section{Publisher's Note}

Springer Nature remains neutral with regard to jurisdictional claims in published maps and institutional affiliations.

Ready to submit your research? Choose BMC and benefit from:

- fast, convenient online submission

- thorough peer review by experienced researchers in your field

- rapid publication on acceptance

- support for research data, including large and complex data types

- gold Open Access which fosters wider collaboration and increased citations

- maximum visibility for your research: over $100 \mathrm{M}$ website views per year

At $\mathrm{BMC}$, research is always in progress.

Learn more biomedcentral.com/submissions 